\title{
Rmg7, a New Gene for Resistance to Triticum Isolates of Pyricularia oryzae Identified in Tetraploid Wheat
}

\author{
Analiza Grubanzo Tagle, Izumi Chuma, and Yukio Tosa
}

Graduate School of Agricultural Sciences, Kobe University, Kobe 657-8501, Japan.

Accepted for publication 7 October 2014.

\begin{abstract}
Tagle, A. G., Chuma, I., and Tosa, Y. 2015. Rmg7, a new gene for resistance to Triticum isolates of Pyricularia oryzae identified in tetraploid wheat. Phytopathology 105:495-499.

A single gene for resistance, designated $R m g 7$ (Resistance to Magnaporthe grisea 7), was identified in a tetraploid wheat accession, St24 (Triticum dicoccum, KU120), against Br48, a Triticum isolate of Pyricularia oryzae. Two other wheat accessions, St17 (T. dicoccum, KU112) and St25 (T. dicoccum, KU122), were also resistant against $\mathrm{Br} 48$ and showed a similar

disease reaction pattern to $\mathrm{St} 24$. Crosses between these resistant accessions yielded no susceptible $F_{2}$ seedlings, suggesting that St24, St17, and St25 carry the same resistance gene. Furthermore, a single avirulence gene corresponding to $R m g 7$ was detected in a segregation analysis of random $\mathrm{F}_{1}$ progenies between $\mathrm{Br} 48$ and MZ5-1-6, an Eleusine isolate virulent to $\mathrm{St} 24$ at a higher temperature. This avirulence gene was recognized not only by St24, but also by St17 and St25, thus supporting the preceding results indicating that all three accessions carry Rmg7. This resistance gene may have potential in future wheat breeding programs.
\end{abstract}

Blast caused by Pyricularia spp. is one of the most devastating plant diseases of monocot species worldwide. Pyricularia oryzae Cav. (Magnaporthe oryzae) (12) is the most common fungal species among causal agents of blast disease of gramineous plants $(4,8)$. This species is divided into subgroups defined by their restricted ranges of host species such as Oryza isolates pathogenic on Oryza spp. including rice, Setaria isolates pathogenic on Setaria spp. including foxtail millet, Eleusine isolates pathogenic on Eleusine spp. including finger millet, etc. $(8,14)$. It is also continuously evolving new host-specific forms, and hence has a potential to cause destructive epidemics on plant species not reported as primary hosts (18). Such epidemics occurred on wheat in the 1980s (19) and on perennial ryegrass in the 1990s (18). They were caused by new subgroups, Triticum isolates and Lolium isolates, respectively.

Wheat blast was reported for the first time in Brazil, from the northern part of the state of Parana in 1985 (5), and then rapidly spread to other countries, and is now a serious threat to wheat production in South America (9). This disease has been reported to cause yield losses ranging from 10 to $100 \%(2,9)$. Higher yield losses occur when favorable climatic conditions occur at the critical growth stages for infection $(2,19)$. In 2011, a soil scientist found blast on a single wheat spike at a University of Kentucky Research and Education Center research plot in Princeton (15). This infection was due to a new strain similar to U.S. Lolium isolates and not a Triticum isolate from South America (15). Although a serious outbreak has not yet been reported outside South America, there is an increasing fear that it could become a threat to wheat production in other parts of the world (9).

As in the case of rice blast disease, the best disease management strategy for wheat blast should combine cultivar resistance with appropriate agronomic practices. The identification of resistance genes to the wheat blast fungus is an important step in developing a disease management strategy (20). To date, few resistance genes

Corresponding author: Y. Tosa; E-mail address: tosayuki@kobe-u.ac.jp

*The $\boldsymbol{e}$-Xtra logo stands for "electronic extra" and indicates that one supplementary table is published online.

http://dx.doi.org/10.1094/PHYTO-06-14-0182-R

(C) 2015 The American Phytopathological Society effective against wheat blast isolates have been identified $(2,20)$. Although some wheat cultivars, such as 'BR 18 Terena', 'BRS 229', and 'MGS 3 Brilhante', showed promising performances under field conditions, their tolerances were unpredictable depending on field location (10). In order to effectively breed for blast resistance in host crop species, more information is required regarding genetic variation in disease response and its inheritance (7), as well as the structure and stability of corresponding avirulence genes in the blast fungus (1).

In this study, we identified a new blast resistance gene in tetraploid wheat accessions using a Triticum isolate $(\mathrm{Br} 48)$ collected in Brazil. We also identified its corresponding avirulence gene by using an Eleusine isolate (MZ5-1-6) as a mating partner.

\section{MATERIALS AND METHODS}

Fungal materials. Fourteen Triticum isolates collected in Brazil from 1990 to 1992 were used for a preliminary survey (Supplementary Table 1). One aggressive isolate, $\mathrm{Br} 48$, was selected from these Triticum isolates and was used for segregation analyses of wheat $\mathrm{F}_{2}$ populations. To identify an avirulence gene, $\mathrm{Br} 48$ (MAT1-1) was crossed with a highly fertile Eleusine isolate (MZ5-1-6 with MAT1-2) collected in Japan in 1976 as described by Murakami et al. (11). One ascospore was isolated from each ascus and transferred to a potato dextrose agar (PDA) slant medium. Consequently, an $\mathrm{F}_{1}$ population composed of 76 random cultures was established. These field isolates and $F_{1}$ cultures have been maintained as described previously (4).

Plant materials. Thirty-four tetraploid wheat accessions employed by Inoue et al. (6) were used for screening. They were provided by M. Tanaka and S. Sakamoto, emeritus professors of Plant Germ-Plasm Institute, Kyoto University, Japan. Based on results of the screening at the seedling stage, four accessions were selected for segregation analyses at the seedling stage; T. dicoccum KU112 (laboratory code St17), KU120 (St24), and KU122 (St25) were resistant to $\mathrm{Br} 48$ whereas T. paleocolchicum KU156 (Tat14) was susceptible (Table 1). $F_{2}$ populations derived from crosses between the resistant and susceptible accessions were used to identify resistance genes against the wheat blast fungus. $F_{2}$ populations derived from crosses between the resistant accessions 
were used for subsequent alellism tests of the resistance genes. T. aestivum 'Thatcher', which carries resistance genes $R m g 2$ and Rmg3 against the wheat blast fungus (22), was used for comparison. Wheat seeds were pregerminated on moistened filter papers for 2 days, sown in vermiculite supplied with liquid fertilizer in a seedling case $(5.5 \times 15 \times 10 \mathrm{~cm})$, and grown at 21 to $24^{\circ} \mathrm{C}$ in a controlledenvironment room with a 12 -h photoperiod of fluorescent lighting for 7 days. Leaves were then fixed onto a hard plastic board for inoculation. Four to five seedlings were used for each wheat accession per replication.

For infection assays at the heading stage, seeds of test plants were sown in an experimental field in November 2013, and grown for 6 months. In May 2014, stems with spikes at the stage of full head emergence were cut at the base, brought back to the laboratory, trimmed to $\approx 50 \mathrm{~cm}$, and put in flasks with water. Spikes of the susceptible accession, Tat 14, could not be harvested simultaneously with those of the resistant accessions, St17, St24, and St25, because Tat14 was late-heading while the three resistant accessions were early-heading. As susceptible controls for assays at the heading stage, we therefore selected three early-heading tetraploid accessions, T. orientale KU137 (Tat7), T. abyssinicum KU185 (Tat18), and T. durum KU329 (St41) from those that showed high susceptibility to Br48 at the seedling stage in the preliminary screening. Three spikes were used for each wheat accession per replication.

Infection assay. Infection assays at the seedling stage were conducted following the protocol described by Murakami et al. (11) with minor modifications. P. oryzae isolates from stocks (infected barley seeds) were grown on PDA slants for 1 week. Mycelial plugs from these culture slants were transferred onto oatmeal agar petri dishes and incubated for 7 days. Aerial mycelia on the 7-day-old cultures were removed by rubbing the mycelial surfaces with cotton balls. To induce sporulation, culture plates were exposed to nearultraviolet light $(360 \mathrm{~nm}, 40 \mathrm{~W})$ at $22^{\circ} \mathrm{C}$ for 4 days. The conidia produced were suspended in water and adjusted to a concentration of $1 \times 10^{5}$ spores per $\mathrm{ml}$. Using an air compressor, $20 \mathrm{ml}$ of the spore suspension with $0.01 \%$ Tween 20 was sprayed on the adaxial surface of primary leaves. The inoculated plants were put in trays, covered with cling wrap and aluminum foil to maintain high humidity, and then placed in darkness at 20,22 , and $25^{\circ} \mathrm{C}$ (in growth chambers) or at 21 to $24^{\circ} \mathrm{C}$ (in the controlled-environment room) for $24 \mathrm{~h}$. They were returned to dry condition with fluorescent lighting in the growth chambers or the controlled-environment room and incubated further at the same temperature as that used for the incubation in the humid trays. Symptoms were evaluated 5 days after inoculation based on the color of lesions and the affected leaf area. The affected area was rated on six progressive grades from 0 to $5: 0=$ no visible evidence of infection; $1=$ pinhead spots; $2=$ small lesions $(<1.5 \mathrm{~mm}) ; 3=$ scattered lesions of intermediate size $(<3 \mathrm{~mm}) ; 4=$ large typical lesions; and $5=$ complete blighting of leaf blades. A disease score is composed of a number which denotes the size of lesions and a letter or letters indicating the lesion color: ' $B$ ' for brown; ' $G$ ' for green; and ' $Y$ ' for yellow. Infection types
0 to 5 with brown or yellow lesions were considered resistant, and infection types $3 \mathrm{G}, 4 \mathrm{G}$, and $5 \mathrm{G}$ were taken as susceptible. All infection assays at the seedling stage were repeated at least three times.

In infection assays at the heading stage the harvested spikes were inoculated with conidial suspensions $\left(1 \times 10^{5}\right.$ spores $\left./ \mathrm{ml}\right)$ prepared as described above and were kept in flasks with water. The whole set-up was covered with a plastic bag to maintain high humidity and placed in darkness at $25^{\circ} \mathrm{C}$ in a growth chamber for $24 \mathrm{~h}$. The plastic bag was removed and the set-up was incubated further at the same temperature with 12 -h alternate light and dark conditions. Five days after inoculation, spike infections were rated on six progressive grades from 0 to 5: $0=$ no visible evidence of infection; $1=$ pinhead spots; $2=$ small lesions $(<1.5 \mathrm{~mm}) ; 3=$ scattered lesions of intermediate size $(<3 \mathrm{~mm}) ; 4=$ mixture of green and white tissues with no apparent browning caused by hypersensitive reaction; and $5=$ complete blighting of the spike. Infection types 0 to 3 were considered resistant and 4 to 5 were susceptible. All infection assays at the heading stage were repeated twice.

\section{RESULTS}

Infection assays at the seedling stage. In a preliminary screening in the controlled-environment room at 21 to $24^{\circ} \mathrm{C}$ (referred to as room temperature hereafter) we found three accessions, St17, St24, and St25 (Fig. 1A), which were resistant to all Triticum isolates tested. To test the temperature sensitivity of resistance, the accessions were inoculated with the representative isolate, $\mathrm{Br} 48$, and incubated in growth chambers at 20, 22, and $25^{\circ} \mathrm{C}$. They were highly resistant at 20 and $22^{\circ} \mathrm{C}$ and resistant at $25^{\circ} \mathrm{C}$ (Table 1). Thus, the following segregation analyses with $\mathrm{F}_{2}$ seedlings were performed in the controlled-environment room (at room temperature).

When an $\mathrm{F}_{2}$ population derived from a cross between $\mathrm{St} 24$ and Tat14 (highly susceptible) (Fig. 1A, Table 1) was inoculated with $\mathrm{Br} 48$, resistant and susceptible seedlings clearly segregated (Fig. 1B) in a 3:1 ratio characterizing a single gene for resistance (Table 2). This gene was designated as $R m g 7$ (Resistance to Magnaporthe grisea 7). The other two crosses, St17 $\times$ Tat14 and St $25 \times$ Tat 14 , also produced resistant and susceptible $F_{2}$ seedlings in 3:1 ratios (Table 2). By contrast, crosses between the resistant accessions (St24 $\times$ St17, St24 $\times$ St25) yielded no susceptible $F_{2}$ seedlings (Table 2). These results suggest that resistance in St17 and St 25 was also controlled by $R m g 7$.

To identify an avirulence gene corresponding to $R m g 7$, an isolate virulent on the $R m g 7$ carriers is needed as a mating partner of $\mathrm{Br} 48$. As mentioned earlier, however, all of the Triticum isolates tested were avirulent on the three accessions. To find a mating partner, the three accessions were inoculated with isolates from rice, foxtail millet, common millet, finger millet, and perennial ryegrass, and incubated at 20,22 , and $25^{\circ} \mathrm{C}$. Interestingly, an Eleusine isolate, MZ5-1-6, was virulent on these resistant accessions at higher

TABLE 1. Infection types of wheat accessions with Triticum isolate Br48 and Eleusine isolate MZ5-1-6 of Pyricularia oryzae

\begin{tabular}{|c|c|c|c|c|c|c|c|}
\hline \multirow[b]{3}{*}{ Plant accession } & \multirow[b]{3}{*}{ Lab code } & \multicolumn{6}{|c|}{ Infection type ${ }^{a}$} \\
\hline & & \multicolumn{3}{|c|}{$\mathrm{Br} 48$} & \multicolumn{3}{|c|}{ MZ5-1-6 } \\
\hline & & $20^{\circ} \mathrm{C}$ & $22^{\circ} \mathrm{C}$ & $25^{\circ} \mathrm{C}$ & $20^{\circ} \mathrm{C}$ & $22^{\circ} \mathrm{C}$ & $25^{\circ} \mathrm{C}$ \\
\hline T. aestivum 'Thatcher' & $\mathrm{Tc}$ & $1 \mathrm{~B}(\mathrm{R})$ & $1-2 B(R)$ & 2BG(R) & $0(\mathrm{R})$ & $0(\mathrm{R})$ & $0(\mathrm{R})$ \\
\hline T. dicoccum KU112 & St17 & $1 \mathrm{~B}(\mathrm{R})$ & $0-1 \mathrm{~B}(\mathrm{R})$ & $1-2 B(R)$ & $0-1 \mathrm{~B}(\mathrm{R})$ & $2 \mathrm{~B}(\mathrm{R})$ & $5 \mathrm{G}(\mathrm{s})$ \\
\hline T. dicoccum KU120 & $\mathrm{St} 24$ & $0-1 \mathrm{~B}(\mathrm{R})$ & $1 \mathrm{~B}(\mathrm{R})$ & $2-3 B(R)$ & $0(\mathrm{R})$ & $1-2 B(R)$ & $5 \mathrm{G}(\mathrm{s})$ \\
\hline T. dicoccum KU122 & $\mathrm{St} 25$ & $0-1 \mathrm{~B}(\mathrm{R})$ & $0-1 \mathrm{~B}(\mathrm{R})$ & $1-2 B(R)$ & $0(\mathrm{R})$ & $0-1 \mathrm{~B}(\mathrm{R})$ & $5 \mathrm{G}(\mathrm{s})$ \\
\hline T. paleocolchicum KU156 & Tat14 & $5 \mathrm{G}(\mathrm{s})$ & $5 \mathrm{G}(\mathrm{s})$ & $5 \mathrm{G}(\mathrm{s})$ & $3 \mathrm{BY}(\mathrm{R})$ & $5 \mathrm{G}(\mathrm{s})$ & $5 \mathrm{G}(\mathrm{s})$ \\
\hline
\end{tabular}

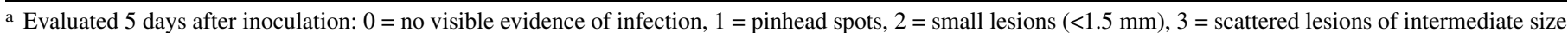
$(<3 \mathrm{~mm}), 4=$ large typical lesions, and $5=$ complete blighting of leaf blades; and brown (B), green (G), and yellow (Y) lesions. (R) and (s) represent resistant and susceptible reactions, respectively. 
temperature $\left(25^{\circ} \mathrm{C}\right)$ (Table 1$) . \mathrm{Br} 48$ (MAT1-1) was crossed with MZ5-1-6 (MAT1-2) to produce an $\mathrm{F}_{1}$ population of 76 random cultures.

When the resistant accessions were inoculated with the $F_{1}$ cultures and incubated at $25^{\circ} \mathrm{C}$, virulent and avirulent cultures segregated in a 1:1 ratio (Table 3 ). The segregation patterns on the three accessions were perfectly concordant (Table 4), suggesting that the avirulence of $\mathrm{Br} 48$ on the three accessions was controlled by the same, single gene. This avirulence gene was designated AVR-Rmg7.

Common wheat cultivar Thatcher carrying Rmg2 and Rmg3 was resistant to both parental isolates (Br48 and MZ5-1-6) even at $25^{\circ} \mathrm{C}$ (Table 1 ). When 'Thatcher' was inoculated with the $\mathrm{F}_{1}$ cultures and incubated at $25^{\circ} \mathrm{C}$, however, virulent and avirulent cultures segregated in a ratio that was not significantly different from 3:1 or 7:1 (Table 3). The segregation pattern on 'Thatcher' was independent from those on St17, St24, and St25 (Table 4), indicating that $A V R-R m g 7$ is not involved in avirulence on 'Thatcher'.
Infection assays at the heading stage. To check whether the resistant accessions could show the same reaction against the blast fungus at the heading stage, spikes of these accessions together with those of the susceptible tetraploid controls were inoculated with $\mathrm{Br} 48$ and incubated at $25^{\circ} \mathrm{C}$ which is more or less similar to the maximum temperature in the field at the heading stage. Five days after inoculation, spikes of the resistant wheat accessions, St17, St24, and St25, showed infection type 2 with small brown lesions caused by hypersensitive reaction (Fig. 2). By contrast, those of the susceptible controls, Tat7, Tat18, and St41, showed infection types 4 to 5 characterized by a mixture of green and white tissues to completely blighted spikes (Fig. 2).

\section{DISCUSSION}

In this study we identified $\operatorname{Rmg} 7$, a dominant gene conferring strong resistance to the wheat blast fungus, in tetraploid wheat accessions St17, St24, and St25 (Table 2). This is the first gene for

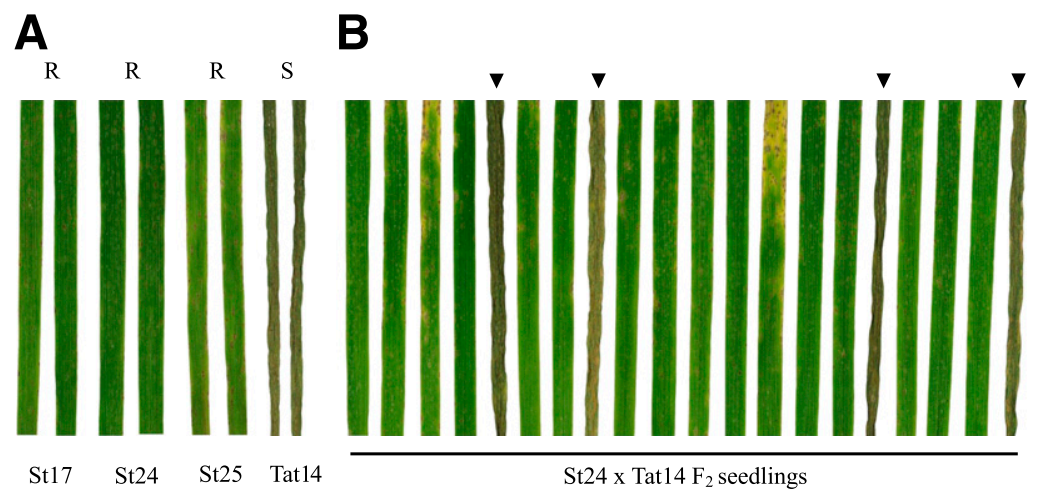

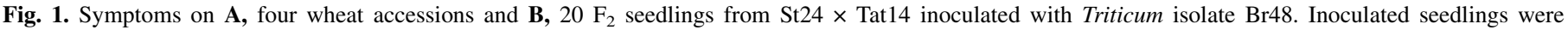
incubated at room temperature for 5 days. R, resistant parent; $\mathrm{S}$, susceptible parent. Arrowheads in B indicate susceptible $\mathrm{F}_{2}$ seedlings.

TABLE 2. Segregation of reactions to Triticum isolate $\mathrm{Br} 48$ in $\mathrm{F}_{2}$ populations derived from crosses between wheat accessions

\begin{tabular}{|c|c|c|c|c|c|c|c|c|c|c|c|c|c|}
\hline \multirow[b]{2}{*}{ Cross } & \multicolumn{11}{|c|}{ Number of $F_{2}$ seedlings } & \multirow[b]{2}{*}{$\chi^{2}(3: 1)$} & \multirow[b]{2}{*}{$P$} \\
\hline & $0 / 1 \mathrm{~B}^{\mathrm{a}}$ & $2 \mathrm{~B}$ & $3 \mathrm{~B} / 3 \mathrm{BG}$ & $4 \mathrm{~B} / 4 \mathrm{BG}$ & $5 \mathrm{~B} / 5 \mathrm{BG}$ & $3 \mathrm{G}$ & $4 \mathrm{G}$ & $5 \mathrm{G}$ & Total & Resistant $^{\mathrm{b}}$ & Susceptible $^{\mathrm{c}}$ & & \\
\hline St17 $\times$ Tat 14 & 13 & 13 & 23 & 37 & 77 & 0 & 0 & 58 & 221 & 163 & 58 & 0.183 & 0.669 \\
\hline St $24 \times$ Tat 14 & 112 & 86 & 61 & 33 & 53 & 0 & 0 & 112 & 457 & 345 & 112 & 0.059 & 0.808 \\
\hline St $25 \times$ Tat 14 & 15 & 13 & 32 & 17 & 104 & 0 & 0 & 55 & 236 & 181 & 55 & 0.362 & 0.548 \\
\hline $\mathrm{St} 24 \times \mathrm{St} 17$ & 400 & 0 & 0 & 0 & 0 & 0 & 0 & 0 & 400 & 400 & 0 & - & - \\
\hline $\mathrm{St} 24 \times \mathrm{St} 25$ & 400 & 0 & 0 & 0 & 0 & 0 & 0 & 0 & 400 & 400 & 0 & - & - \\
\hline
\end{tabular}

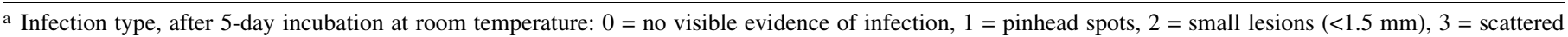
lesions of intermediate size $(<3 \mathrm{~mm}), 4=$ large typical lesions, and $5=$ complete blighting of leaf blades; and brown $(\mathrm{B})$ and green $(\mathrm{G})$ lesions.

b Infection type 0 to $5 \mathrm{BG}$.

c Infection type $3 \mathrm{G}$ to $5 \mathrm{G}$

TABLE 3. Segregation of virulence on wheat accessions in an $\mathrm{F}_{1}$ population derived from MZ5-1-6 $\times$ Br48

\begin{tabular}{|c|c|c|c|c|c|c|c|c|c|c|c|c|c|c|}
\hline \multirow[b]{2}{*}{ Plant accession } & \multicolumn{11}{|c|}{ Number of $F_{1}$ cultures } & \multicolumn{3}{|c|}{$\chi^{2}$ for } \\
\hline & $0 / 1 \mathrm{~B}^{\mathrm{a}}$ & $2 \mathrm{~B}$ & $3 \mathrm{~B} / 3 \mathrm{BG}$ & $4 \mathrm{~B} / 4 \mathrm{BG}$ & $5 \mathrm{~B} / 5 \mathrm{BG}$ & $3 \mathrm{G}$ & $4 \mathrm{G}$ & $5 \mathrm{G}$ & Avirulent $^{\mathrm{b}}$ & Virulent $^{c}$ & Total & $1: 1$ & $3: 1$ & $7: 1$ \\
\hline St17 & 24 & 7 & 8 & 0 & 0 & 0 & 0 & 37 & 39 & 37 & 76 & 0.05 & $22.74^{\mathrm{d}}$ & $90.98^{\mathrm{d}}$ \\
\hline $\mathrm{St} 24$ & 24 & 7 & 8 & 0 & 0 & 0 & 0 & 37 & 39 & 37 & 76 & 0.05 & $22.74^{\mathrm{d}}$ & $90.98^{d}$ \\
\hline St25 & 24 & 7 & 8 & 0 & 0 & 0 & 0 & 37 & 39 & 37 & 76 & 0.05 & $22.74^{\mathrm{d}}$ & $90.98^{\mathrm{d}}$ \\
\hline $\mathrm{Tc}$ & 30 & 17 & 13 & 1 & 1 & 3 & 4 & 7 & 62 & 14 & 76 & $30.32^{\mathrm{d}}$ & 1.75 & 2.44 \\
\hline Tat14 & 0 & 0 & 0 & 0 & 0 & 0 & 0 & 76 & 0 & 76 & 76 & - & - & - \\
\hline
\end{tabular}

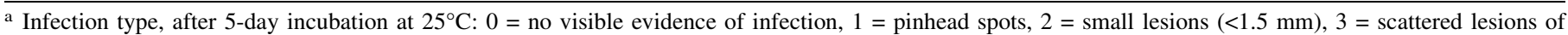
intermediate size $(<3 \mathrm{~mm}), 4=$ large typical lesions, and $5=$ complete blighting of leaf blades; and brown (B) and green (G) lesions.

b Infection type 0 to $5 \mathrm{BG}$.

c Infection type $3 \mathrm{G}$ to $5 \mathrm{G}$.

d Significant at $P=0.01$. 
resistance to Triticum isolates of $P$. oryzae identified in tetraploid wheat. We also identified its corresponding avirulence gene, AVR$R m g 7$ (Table 3). This gene was recognized by all three accessions, St17, St24, and St25 (Table 4), supporting the hypothesis that they share the same resistance gene ( $R m g 7)$ in a gene-for-gene relationship.

Seven blast resistance genes have been reported in wheat. $\operatorname{RmgTd}(t)$, identified in T. dicoccoides KU109 (Tat4) is a "hidden" resistance gene that does not confer resistance against field isolates (3). All the other resistance genes were from hexaploid cultivars. Rmgl (Rwt4) was identified in common wheat cultivar Norin 4 and found to be effective against an Avena isolate (16). Zhan et al. (22) subsequently identified two resistance genes in common wheat cultivar Thatcher and designated them as Rmg2 and Rmg3. They were effective against their own subgroup, Triticum isolates. Nga et al. (13) identified two resistance genes designated as Rmg4 and Rmg5 in common wheat cultivars Norin 4 and Red Egyptian, respectively. They were effective against another species, $P$. grisea, isolated from crabgrass. Rmg6, another gene found in 'Norin 4' was effective against a Lolium isolate (21). Rmg7 should be different from Rmg1, Rmg4, Rmg5, and Rmg6, because these four genes are not effective against Br48 (13,16,21). Also, Rmg7 should be different from $R m g 2$ and $R m g 3$ because it corresponds to an avirulence gene (AVR-Rmg7) different from those corresponding to Rmg2 and Rmg3 in 'Thatcher' (Table 4) as described below.

'Thatcher' is resistant to both Br48 and MZ5-1-6. Its resistance to $\mathrm{Br} 48$ is controlled by two genes, Rmg 2 and Rmg3. Therefore, at least three genes should be involved in avirulence on 'Thatcher' of the $\mathrm{F}_{1}$ population derived from MZ5-1- $6 \times \mathrm{Br} 48$; at least one from MZ5-1-6 and two from Br48. The actual segregation ratio was not significantly different from a 7:1 ratio (trifactorial segregation) (Table 3). The combined segregation (Table 4) indicated that $A V R$ $R m g 7$ is different from the three avirulence genes on 'Thatcher'.

TABLE 4. Combined segregation of virulence on two wheat accessions in an $\mathrm{F}_{1}$ population derived from MZ5-1-6 $\times \mathrm{Br} 48$

\begin{tabular}{|c|c|c|c|c|c|c|}
\hline \multicolumn{2}{|c|}{$\begin{array}{c}\text { Plant } \\
\text { accessions }\end{array}$} & \multicolumn{5}{|c|}{ Number of $F_{1}$ cultures } \\
\hline $\mathrm{p}$ & $q$ & $\mathrm{ApAq}^{\mathrm{a}}$ & $\mathrm{ApVq}$ & $\mathrm{VpAq}$ & $\mathrm{VqVq}$ & Total \\
\hline $\mathrm{St} 24$ & St17 & 39 & 0 & 0 & 37 & 76 \\
\hline St24 & St25 & 39 & 0 & 0 & 37 & 76 \\
\hline St24 & $\mathrm{Tc}$ & 33 & 6 & 29 & 8 & 76 \\
\hline
\end{tabular}

a A, avirulent (infection type 0 to $5 \mathrm{BG}$ ); and $\mathrm{V}$, virulent (infection type $3 \mathrm{G}$ to 5G). For example, ApVq represents cultures that are avirulent on $\mathrm{p}$ and virulent on $\mathrm{q}$.
Chuma et al. (1) investigated how rapid adaptation of a pathogen can cause a breakdown of resistance in newly developed resistant cultivars. The results of their study clarified how the structure and genome location of an avirulence gene can affect the effectiveness or durability of its corresponding resistance gene. Based on this finding, Tosa and Chuma (17) suggested that we might be able to predict the durability of resistance genes by estimating the stability of their corresponding avirulence genes. The first step for the prediction is to identify corresponding avirulence genes. One critical problem is that, for identification of an avirulence gene corresponding to a resistance gene $(R l)$, an isolate virulent to $R l$ is needed as a mating partner. However, a new, promising resistance gene expected to be durable must be effective against all prevailing isolates at least before its release to farmer's field. Actually, the three accessions carrying $R m g 7$ were resistant to all Triticum isolates tested. To identify the avirulence gene corresponding to $R m g 7$, we screened various isolates of $P$. oryzae other than Triticum isolates. Such isolates are basically avirulent on wheat due to hostgenus specificity. However, we found that avirulence was occasionally compromised by higher temperatures (Table 1). By using the temperature sensitivity of avirulence of Eleusine isolate MZ5-16, we successfully identified $A V R-R m g 7$. The next step is to clone this avirulence gene. Once cloned, its stability may be estimated based on its chromosomal location, molecular structure around it, and effects of their mutations on fitness of the fungus (17), which might lead to the prediction of durability of its corresponding resistance gene, $R m g 7$.

Cruz et al. (2) and Maciel et al. (10) reported that there was no strong correlation between seedling and spike reactions to the wheat blast pathogen. The Rmg genes have been identified using seedlings. They included two genes effective against Triticum isolates, Rmg2 and Rmg3, identified in 'Thatcher'. When spikes of 'Thatcher' were inoculated with $\mathrm{Br} 48$, they were susceptible to moderately resistant (unpublished data). On the other hand, St17, St24, and St25 were highly resistant to $\mathrm{Br} 48$ even at the heading stage (Fig. 2). It should be tested whether this resistance at the heading stage is also controlled by Rmg7. If this is the case, it will increase the potential of this resistance gene for future breeding to counter the growing threat of blast epidemics in wheat.

\section{ACKNOWLEDGMENTS}

We thank M. Tanaka and S. Sakamoto, emeritus professors of Kyoto University, Japan, for providing the tetraploid accessions; M. Terada, Kobe University, for crossing the isolates; and R. McIntosh, University of Sydney, Australia, for critical reading and editing of the manuscript.

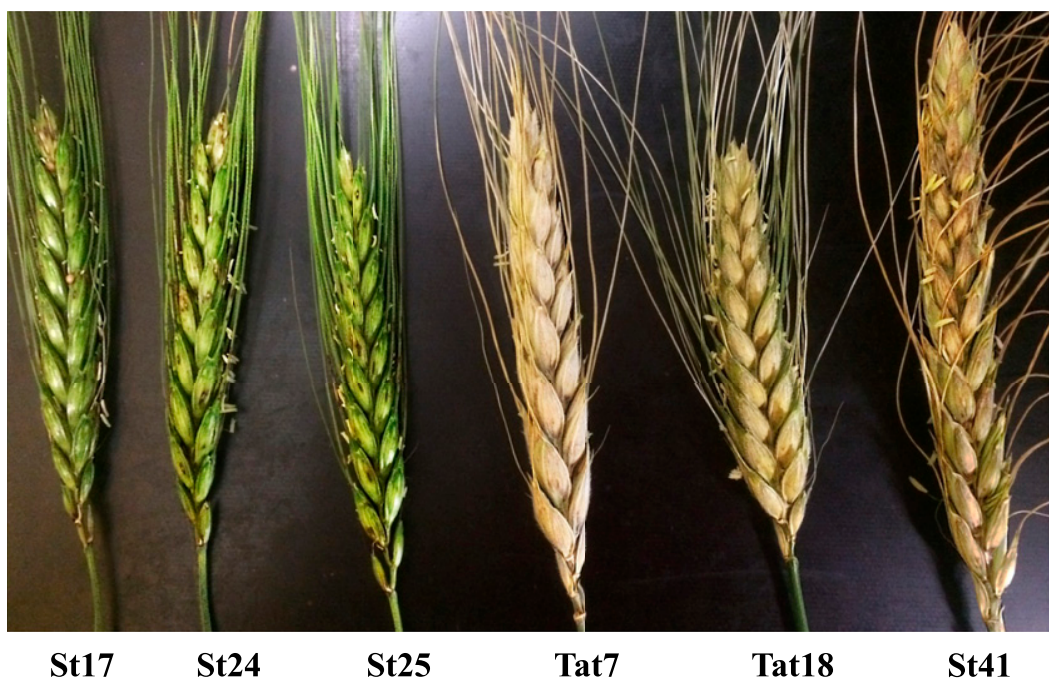

Fig. 2. Spikes of wheat accessions 5 days after inoculation with $\mathrm{Br} 48$ at $25^{\circ} \mathrm{C}$. 


\section{LITERATURE CITED}

1. Chuma, I., Isobe, C., Hotta, Y., Ibaragi, K., Futamata, N., Kusaba, M., Yoshida, K., Terauchi, R., Fujita, Y., Nakayashiki, H., Valent, B., and Tosa, Y. 2011. Multiple translocation of the AVR-Pita effector gene among chromosomes of the rice blast fungus Magnaporthe oryzae and related species. PLoS Pathog. 7:e1002147.

2. Cruz, C. D., Bockus, W. W., Stack, J. P., Tang, X., Valent, B., Pedley, K. F., and Peterson, G. L. 2012. Preliminary assessment of resistance among U.S. wheat cultivars to the Triticum pathotype of Magnaporthe oryzae. Plant Dis. 96:1501-1505.

3. Cumagun, C. J. R., Anh, V. L., Vy, T. T. P., Asano, H., Hyon, G.-S., Inoue, Y., Chuma, I., and Tosa, Y. 2014. Identification of a hidden resistance gene in tetraploid wheat using laboratory strains of Pyricularia oryzae produced by backcrossing. Phytopathology 104:634-640.

4. Hirata, K., Kusaba, M., Chuma, I., Osue, J., Nakayashiki, H., Mayama, S., and Tosa, Y. 2007. Speciation in Pyricularia inferred from multilocus phylogenetic analysis. Mycol. Res. 111:799-808.

5. Igarashi, S., Utiamada, C. M., Igarashi, L. C., Kazuma, A. H., and Lopes, R. S. 1986. Pyricularia in wheat. 1. Occurrence of Pyricularia sp. in Parana State. (In Portuguese) Fitopatol. Bras. 11:351-352.

6. Inoue, Y., Mori, R., Takahashi, Y., Kiguchi, S., Enomoto, T., Chuma, I., and Tosa, Y. 2013. Identification and molecular mapping of a wheat gene for resistance to an unadapted isolate of Colletotrichum cereale. Phytopathology 103:575-582.

7. Inukai, T., Vales, M. I., Hori, K., Sato, K., and Hayes, P. M. 2006. RMo1 confers blast resistance in barley and is located within the complex of resistance genes containing Mla, a powdery mildew resistance gene. Mol. Plant-Microbe Interact. 19:1034-1041.

8. Kato, H., Yamamoto, M., Yamaguchi-Ozaki, T., Kadouchi, H., Iwamoto, Y., Nakayashiki, H., Tosa, Y., Mayama, S., and Mori, N. 2000. Pathogenicity, mating ability and DNA restriction fragment length polymorphisms of Pyricularia populations isolated from Gramineae, Bambusideae and Zingiberaceae plants. J. Gen. Plant Pathol. 66:30-47.

9. Kohli, M. M., Mehta, Y. R., Guzman, E., de Viedma, L., and Cubilla, L. E. 2011. Pyricularia blast - A threat to wheat cultivation. Czech J. Genet. Plant Breed. 47:S130-S134.

10. Maciel, J. L. N., Ceresini, P. C., Castroagudin, V. L., Zala, M., Kema, G. H. J., and McDonald, B. A. 2014. Population structure and pathotype diversity of the wheat blast pathogen Magnaporthe oryzae 25 years after its emergence in Brazil. Phytopathology 104:95-107.
11. Murakami, J., Tosa, Y., Kataoka, T., Tomita, R., Kawasaki, J., Chuma, I., Sesumi, Y., Kusaba, M., Nakayashiki, H., and Mayama, S. 2000. Analysis of host species specificity of Magnaporthe grisea toward wheat using a genetic cross between isolates from wheat and foxtail millet. Phytopathology 90:1060-1067.

12. Murata, N., Aoki, T., Kusaba, M., Tosa, Y., and Chuma, I. 2014. Various species of Pyricularia constitute a robust clade distinct from Magnaporthe salvinii and its relatives in Magnaporthaceae. J. Gen. Plant Pathol. 80:66-72.

13. Nga, N. T., Hau, V. T., and Tosa, Y. 2009. Identification of genes for resistance to a Digitaria isolate of Magnaporthe grisea in common wheat cultivars. Genome 52:801-809.

14. Oh, H. S., Tosa, Y., Takabayashi, N., Nakagawa, S., Tomita, R., Don, L. D., Kusaba, M., Nakayashiki, H., and Mayama, S. 2002. Characterization of an Avena isolate of Magnaporthe grisea and identification of a locus conditioning its specificity on oat. Can. J. Bot. 80:1088-1095.

15. Pratt, K. 2012. UK researchers find important new disease. In: UK College of Agriculture News. College of Agriculture, University of Kentucky, Lexington. http://news.ca.uky.edu/article/uk-researchers-find-importantnew-disease

16. Takabayashi, N., Tosa, Y., Oh, H. S., and Mayama, S. 2002. A gene-forgene relationship underlying the species-specific parasitism of Avenal Triticum isolates of Magnaporthe grisea on wheat cultivars. Phytopathology 92:1182-1188.

17. Tosa, Y., and Chuma, I. 2014. Classification and parasitic specialization of blast fungi. J. Gen. Plant Pathol. 80:202-209.

18. Tosa, Y., Hirata, K., Tamba, H., Nakagawa, S., Chuma, I., Isobe, C., Osue, J., Urashima, A. S., Don, L. D., Kusaba, M., Nakayashiki, H., Tanaka, A., Tani, T., Mori, N., and Mayama, S. 2004. Genetic constitution and pathogenicity of Lolium isolates of Magnaporthe oryzae in comparison with host speciesspecific pathotypes of the blast fungus. Phytopathology 94:454-462.

19. Urashima, A. S., Igarashi, S., and Kato, H. 1993. Host range, mating type and fertility of Pyricularia grisea from wheat in Brazil. Plant Dis. 77:1211-1216.

20. Urashima, A. S., Lavorent, N. A., Goulart, A. C. P., and Mehta, R. 2004. Resistance spectra of wheat cultivars and virulence diversity of Magnaporthe grisea isolates in Brazil. Fitopatol. Bras. 29:511-518.

21. Vy, T. T. P., Hyon, G., Nga, N. T. T., Inoue, Y., Chuma, I., and Tosa, Y. 2014. Genetic analysis of host-pathogen incompatibility between Lolium isolates of Pyricularia oryzae and wheat. J. Gen. Plant Pathol. 80:59-65.

22. Zhan, S. W., Mayama, S., and Tosa, Y. 2008. Identification of two genes for resistance to Triticum isolates of Magnaporthe oryzae in wheat. Genome 51:216-221. 